\title{
METHOD OF PRELIMINARY EVALUATING THE POSSIBILITY OF MODIFYING THE COATING OF ELECTRODES WITH NANOSIZED PARTICLES IN PROCESS 111
}

\author{
Plamen TASheV \\ Institute of Metal Science, Equipment and Technologies, \\ with Hydro- and Aerodynamics Centre "Acad. A. Balevski", \\ Bulgarian Academy of Sciences, \\ 67, Shipchenski Prohod Blvd, 1574 Sofia, Bulgaria, \\ e-mail:weld@abv.bg
}

The manufacture of coated electrodes for manual arc welding is a complex technological process. The development and manufacture of electrodes with nanosized particles introduced in the coating requires considerable scientific and production resources. The subject of the present study is to develop an express method of introducing nanosized particles in the coating of electrodes for manual arc welding aimed to modifying the structure of the weld metal and to improving its mechanical properties. This will give possibility for preliminary assessment of the effect of different nanomodifiers introduced in the coating of the electrodes on the structure and the mechanical properties of the weld metal.

Keywords: coated electrodes, manual arc welding, nanomodifiers, overlay welding.

\section{INTRODUCTION}

Extending the life cycle of machine parts is the foundation of a number of scientific studies. One of the methods used is overlay welding of parts and recovery of worn surfaces. The manual arc welding is widely spread in practice. From the point of view of technology the overlay welding is a variety of welding, in which coated electrodes are used in manual arc welding. This method is particularly efficient when nanomodifiers are introduced in the overlay metal to modify the structure of the layer and to improve its mechanical properties.

There is an increased interest in nanomaterials observed in the scientific research and the engineering practice. The topicality of these studies is determined by the properties of those materials, their application capabilities

DOI: 10.7546/EngSci.LV.18.03.04

(C) Инженерни науки, год. LV, 2018, № 3

52

(c) Engineering Sciences, LV, 2018, No. 3 
and the possibility to create qualitatively new technologies and materials. A major type of nanosized particles used for modification is titanium-containing one, mainly titanium dioxide, titanium, titanium carbonitride [1-3].

There are different technologies [4] to introduce nanomodifiers in the liquid phase of the weld metal.

The coated electrodes are obtained through compression the coating onto a metal rod. The nanosized particles are introduced in the coating in the process of manufacture of the electrodes.

An innovative technology is developed and nanomodified coated electrodes are manufactured with addition of titanium nitride, chrome-cladded titanium nitride, alumina, silicon carbide, titanium carbonitride and carbon-cladded titanium carbonitride [5-6]. The testing carried out reveal that the wear resistance and hardness, as well as the microstructure of the overlay metal are significantly improved [7-11].

A method of introducing nanosized particles in the coating of the electrodes by means of immersion the same in water glass emulsion is proposed [12]. The observed increase in the hardness of the overlay welded layers is negligible and the most likely reason is that the nanosized particles are concentrated in the top layer of the coating and are released and emerged to the surface with the slag (Fig. 1).

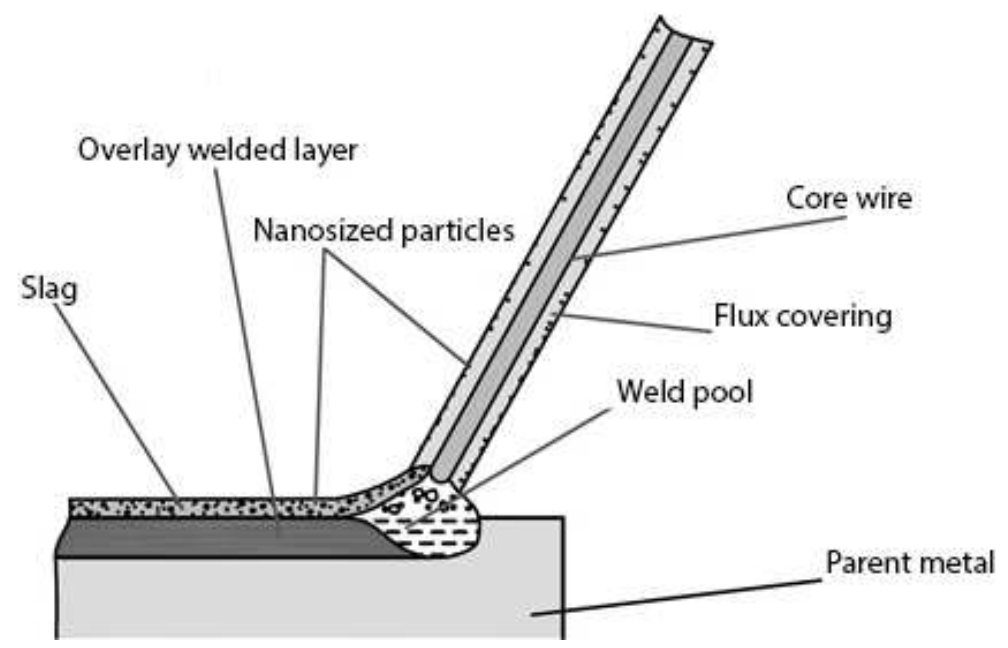

Fig. 1. Illustration for the probable emerging of nanosized particles from the surface of the coating of the electrode to the released slag [12]

(c) Инженерни науки, год. LV, 2018, № 3 


\section{DESCRIPTION OF THE METHOD}

The developed express method for evaluation is based on nanomodification of the liquid phase by means of the coating of the tested electrode. Part of the coating is removed in one or more spots, evenly over the entire length, thus forming a groove with cross-section of rectangular, triangular or another geometrical shape (Fig. 2).
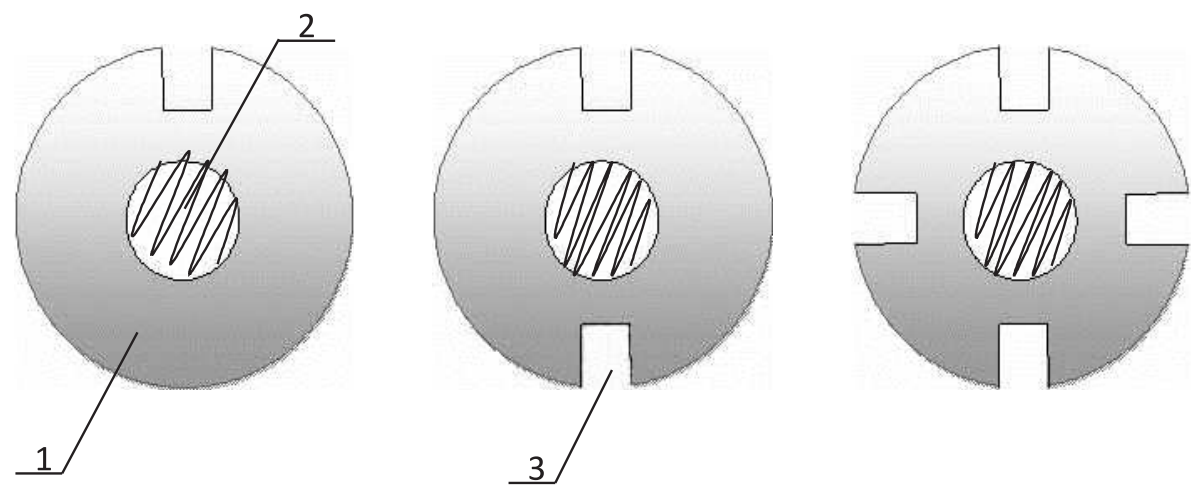

Fig. 2. Cross-section of a tested electrode with part of the coating removed: 1 - coating, 2 - metal core of the electrode, 3 - groove (spots with partially removed coating)

The weight of the coating $T_{c t}[\mathrm{~g}]$ is calculated as the difference between the average weight of ten coated electrodes and the average weight of ten metal cores, all taken at random:

$$
T_{c t}=T_{a v e}-T_{a v m c},
$$

where $T_{a v e}$ is the average weight of a coated electrode, and $T_{a v m c}$ is the average weight of the metal core of the electrode.

The pattern for removal of the coating is selected (Fig. 2). It is advisable to select symmetrical arrangement of the grooves for a more uniform distribution of the introduced nanosized particles. The number of the electrodes for nanomodification is determined and part of the coating is removed. The weight of the coating removed $T_{r} c t[\mathrm{~g}]$ is calculated by weighing the electrodes before and after removing a part of the coating.

Then fresh coating of weight equal to that of the removed coating $T_{r} c t$ is mixed up with the quantity of nanomodifier corresponding to the desired percentage of final nanomodification.

(c) Инженерни науки, год. LV, 2018, № 3 


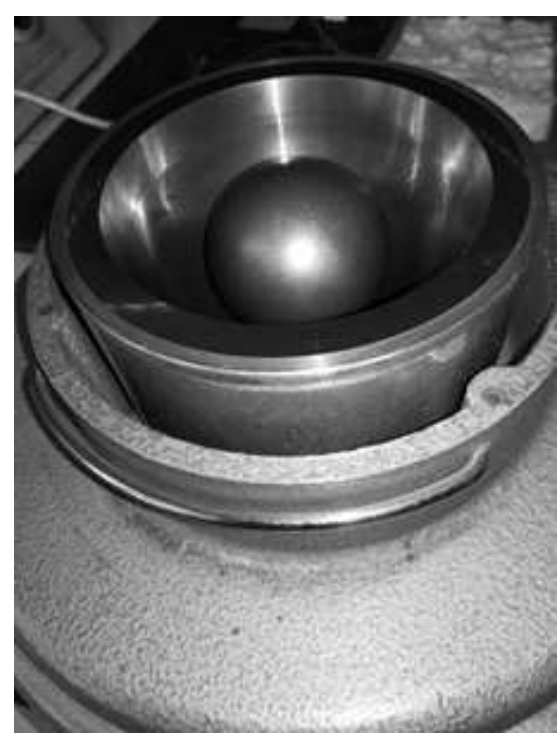

Fig. 3. General view of vibration mill

The resulting mixture is treated in vibration mill (Fig. 3) for a pre-set time in order to homogenize the mixture and to activate the nanosized particles.

Then the powder thus obtained is stirred with a component with adhesive properties, possibly neutral to the welding process. After mixing the nanomodifying paste is filled uniformly in the grooves and the electrodes are dried in oven at $350{ }^{\circ} \mathrm{C}$ for 1 hour.

During the testing the electrodes with nanomodified coating are compared to the reference electrodes of the same grade.

An advantage of the proposed method is the possibility to evaluate the impact of different types and quantities of nanomodifiers on the structure and the properties of coated electrodes for welding and overlay welding of different alloys, as there is no need for the same to be produced by conventional technology and therefore the costs are relatively low. The method is applicable for preliminary tests and evaluation of the impact of the nanomodifier.

\section{EXPERIMENTAL}

Nanomodification of the coating of electrodes for overlay welding of shafts, rails, crossings, screws, gears, etc., with Brinell hardness $\mathrm{HB}>250$ and chemical composition of the overlay metal given in Table 1, is carried out.

(c) Инженерни науки, год. LV, 2018, № 3

55

(c) Engineering Sciences, LV, 2018, No. 3 
TABLE 1. Chemical composition of the overlay metal

\begin{tabular}{|c|c|c|c|}
\hline $\mathrm{C}, \%$ & $\mathrm{Mn}, \%$ & $\mathrm{Si}, \%$ & $\mathrm{Cr}, \%$ \\
\hline $0.1 \div 0.15$ & $1.6 \div 1.8$ & $0.4 \div 0.8$ & $0.8 \div 1.2$ \\
\hline
\end{tabular}

The nanomodifier selected is TiN. The nanomodification of the coating is carried out according to the method described above. The diameter of the electrodes is $\varnothing 4 \mathrm{~mm}$. Overlay welding in three layers is carried out on the precut and cleaned strips measuring $78 \times 60 \times 10 \mathrm{~mm}$ (Fig. 4). The subsequent layers are welded after cooling on air to temperature under $100^{\circ} \mathrm{C}$.

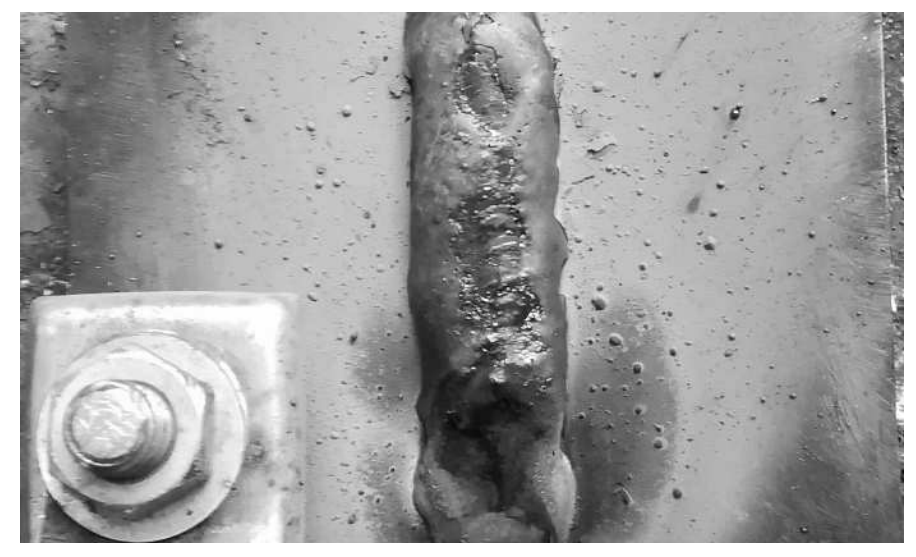

Fig. 4. Strip after three-layer overlay welding

The strips are made of low-carbon structural steel S235JR. The steel grade is selected with view of minimum influence of the weld metal on the parent metal.

The layers of length $50 \mathrm{~mm}$ and width $22 \mathrm{~mm}$ are welded with oscillating motion of the electrode. The overlay welding is carried out with reverse polarity at welding current $170 \mathrm{~A}$. The strips welded with nanomodified electrodes are marked with " $N$ " and the reference ones are marked with " $R$ ".

\section{RESULTS}

After welding each subsequent layer, the formation of welded seam and the type of the slag are visually evaluated. There were no significant changes in the formation of the weld, the type of slag and its separation. In welder's evaluation, there are no changes when burning the electrode. No surface imperfections are found.

(c) Инженерни науки, год. LV, 2018, № 3

56

(c) Engineering Sciences, LV, 2018, No. 3 


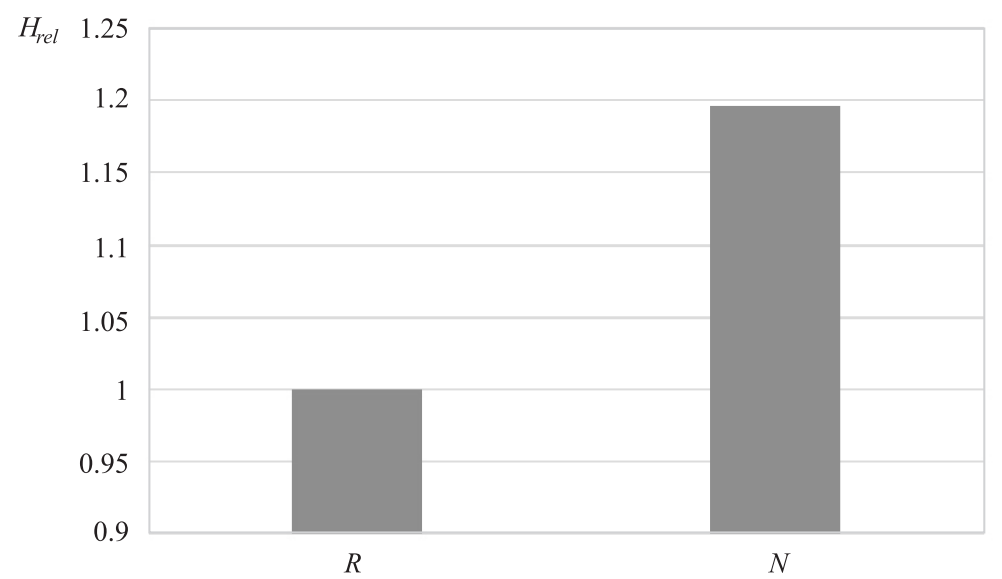

Fig. 5. Increase of hardness of nanomodified samples: $H_{\text {rel }}$ - relative change of hardness after nanomodification; $R$ - reference sample; $H$ - nanomodified sample

After mechanically removing the surface layer, the Brinell hardness is measured.

The Brinell hardness for both the reference and the nanomodified samples are determined as the average of the measured values in twelve points along the weld. In Figure 5 the relative change of the hardness in the reference and the modified sample is shown.

The relative gradient of hardness is determined by the formula:

$$
H_{r e l}=\frac{H_{N}}{H_{R}},
$$

where $H_{N}$ is the hardness of the test sample measured according to the described method, and $H_{R}$ is the hardness of the reference sample measured according to the described method.

The comparison between the reference and the nanomodified sample shows that the hardness of the nanomodified overlay layer is increased with about $20 \%$.

\section{CONCLUSION}

- An innovative method with introduction of nanosized particles in the coating of electrodes for manual arc welding is developed applicable for preliminary testing and evaluation of the effect of different nanomodifiers.

- The method gives possibility for a preliminary evaluation of different types and quantities of nanomodifiers on the structure and properties of coated

(c) Инженерни науки, год. LV, 2018, № 3

57

(C) Engineering Sciences, LV, 2018, No. 3 
electrodes for welding and overlay welding of metals and alloys, which are not necessarily manufactured by the conventional technology and therefore the costs are relatively low.

- The testing carried out proves that the hardness of the nanomodified overlay layer is increased with about $20 \%$.

\section{REFERENCES}

[1] A. Artemev, G. N. Sokolov and V. I. Lysak, Effect of microparticles of titanium diboride and nanoparticles of titanium carbonitride on the structure and properties of deposited metal, Metal Science and Heat Treatment (2012) $\mathbf{5 3}$ (11-12).

[2] Jin-Ju Park And Sung-Mo Hong, Microstructure and properties of SA106B carbon steel after treatment of the melt with nanosized TiC particles, Materials Science $\mathcal{G}$ Engineering A 613 (2014) 217-223.

[3] A. N. Cherepanov et al., On the application of nanosized powders of refractory compounds in welding and processing of metals and alloys, Heavy Engineering (2008) 4 (2) 25-26 (in Russian).

[4] P. Tashev, T. Petrov, Y. Lukarsky and G. Stefanov, Technologies for introduction of nanosized particles the weld seam during the processes of overlay welding, Engineering Sciences (2013) L (3) 82-93, ISSN 1312-5702 (in Bulgarian).

[5] P. Tashev, H. Kondov, Y. Lukarski and E. Tasheva, Development of nano-modified electrodes for manual arc overlay welding and examination of the hardness of the overlaid layer, Engineering Sciences (2015) LII (3) 71-79, ISSN 1312-5702 (in Bulgarian).

[6] P. Tashev, H. Kondov and A. Tasev, Technological properties of nanomodified electrodes for manual arc welding, in: Collection of Papers of Fourth National Conference with International Participation "Metal Science, Hydro- and Aerodynamics , National Security'2014", Sofia, 23-24 October 2014, pp. 75-79, ISSN 1313-8308 (in Bulgarian).

[7] P. Tashev, H. Kondov, M. Kandeva and E. Tasheva, Wear-resistance study of nanomodified coatings by TIG surfacing process, in: SERBIATRIB'15, $14^{\text {th }}$ International Conference on Tribology, Belgrade, Serbia, 13-15 May 2015, ISBN 978-86-7083-857-4.

[8] P. Tashev, H. Kondov, E. Tasheva and M. Kandeva, Study on hardness and wear resistance of layers overlayed using electrodes with nanomodified coating, International Journal of Engineering and Applied Sciences (2015) 6 (4) 01-06, Islamabad, Pakistan, ISSN 2305-8269.

(c) Инженерни науки, год. LV, 2018, № 3

58

(c) Engineering Sciences, LV, 2018, No. 3 
[9] P. Tashev, H. Kondov, E. Tasheva and A. Tasev, Durability of nanomodified layers produced by manual arc overlay welding, in: The $3^{\text {rd }}$ IIW South-East European Welding Congress, "Welding and Joining Technologies for a Sustainable Development and Environment", Timişoara, Romania, June 3-5, 2015, pp. 267-271, ISBN 978-606-554-955-5.

[10] P. Tashev, H. Kondov, R. Lazarova and R. Dimitrova, Research on Nanomodified Layers Obtained in Manual Arc Welding, in: Collection of Reports of $28^{\text {th }}$ International Scientific Conference of the Faculty of Mechanical and Manufacturing Technology of the Technical University of Sofia "70 Years of MTF", Sozopol, 11-13 September 2015, pp. 197-205, ISSN 978-619-167-178-6 (in Bulgarian).

[11] P. Tashev, H. Kondov, S. Valkanov and E. Tasheva, Scanning electron microscope examination of layers weld overlaid with nanomodified electrodes, Academic Journal "Mechanics Transport Communications" (2016) 15 (3/1), article No 1331, ISSN 1312-3823 (Print), ISSN 2367-6620 (Online).

[12] H. Kondov, M. Manilova and P. Tashev, Nanomodification of Electrodes for Process 111 by Immersion, in: Scientific Notifications of NTMC, Days of Nondestructive Control'2018, XXIV International Conference "Defectoscopy'18", Bulgaria, Sozopol, 04-8 June 2018 (in Bulgarian).

\section{МЕТОД ЗА ПРЕДВАРИТЕЛНА ОЦЕНКА НА ВЪЗМОЖНОСТТА ЗА МОДИФИЦИРАНЕ НА ОБМАЗКАТА НА ЕЛЕКТРОДИ С НАНОРАЗМЕРНИ ЧАСТИЦИ ПРИ ПРОЦЕС 111}

\section{ПЛАМЕН ТАШЕВ}

Институт по металознание, съорбжения и технологии с Центгр по хидро- и аеродинамика „Акад. Ангел Балевски“, Българска академия на науките, бул. Шипченски проход № 67, 1574 София, Бглгария, e-mail:weld@abv.bg

Резюме. Производството на обмазани електроди за ръчно електродъгово заваряване е сложен технологичен процес. При разработването и изработването на електроди с добавени в обмазката наночастици се изисква използването на значителен научен и производствен ресурс. Предмет на настоящата статия е разработването на експресен метод за внасяне в обмазката на електроди за ръчно електродъгово заваряване на наноразмерни частици, които да променят структурата на метала на 
шева и да подобрят механичните му свойства. Това ще даде възможност за предварителна оценка на влиянието на различните наномодификатори, добавени в обмазката на електродите, върху структурата и механичните свойства на метала на шева.

Ключови думи: обмазани електроди, ръчно електродъгово заваряване, наномодификатори, наваряване.

Received July 09, 2018 